\title{
Fungi found on Helianthus annuus in Finland
}

\author{
HILKKA KOPONEN and UNTO TULISALO
}

KOPONEN, H. \& TULISALO, U. 1982: Fungi found on Helianthus annuus in Finland. - Karstenia 22: 9-10.

Twenty species of fungi were identified in moist chamber cultures of diseased organs of Helianthus annuus L. Severe infection by Botrytis cinerea Nocca \& Balbis and Sclerotinia sclerotiorum (Lib.) de Bary was demonstrated, and these species together with Fusarium avenaceum (Fr.) Sacc., F. equiseti (Corda) Sacc., F. oxysporum Schlecht. and $F$. sambucinum Fuckel form a disease complex which is very destructive on sunflower stands in Finland. These fungi have not been reported earlier on Helianthus annuus in Finland.

Hilkka Koponen, Department of Botany, University of Helsinki, Unioninkatu 44, SF-00170 Helsinki 17, Finland.

Unto Tulisalo, Agricultural Research Centre, SF-01300 Vantaa 30, Finland.

\section{Materials and methods}

The material for this study was provided by the author Tulisalo from trials with a sunflower (Helianthus annuus L.) variety (Garlic 64, Issanka, Peredovik) at the Agricultural Research Centre, in Vantaa, Tikkurila, Finland (Grid $27^{\circ} \mathrm{E}: 6688: 392$ ). The samples were taken at random from apparently diseased capitula (18 samples), stems (15) and leaves (5), which were in moderately poor condition. Brownish or yellowish lesions occurred on the lamina or petioles of the leaves, and on the stems, which could break off at ground level. Most of the capitula had brownish lesions and soft rot, showing conidia of Botrytis cinerea or white mycelium and black sclerotia of Sclerotinia sclerotiorum. The samples were taken on August 6 and September 24, 1979.

The mycological studies were carried out in the Institute of Plant Pathology of the Agricultural Research Centre, Tikkurila. In the analyses two methods were used: 1) In the filter paper method about $1-\mathrm{cm}^{3}$ pieces of diseased plant were placed in Petri dishes (14 cm in diam.), in which there were one cotton filter and two filter papers, wetted with distillated water $(20 \mathrm{ml})$. The plant pieces in the Petri dishes were about $1 \mathrm{~cm}$ apart, never touching each other. During the first two weeks the dishes were kept in room temperature (about $+24^{\circ} \mathrm{C}$ ) in diffuse daylight and for the following two weeks in $+5^{\circ} \mathrm{C}$ in the dark. 2) In the agar method pieces of plants were disinfected with absolute alcohol for two minutes, dried and flamed. They were then placed on potato dextrose agar (PDA, Difco) in Petri dishes (9 $\mathrm{cm}$ in diam.) in the same way as in the filter paper method and kept in diffuse daylight all the time. The fungi on the agar were determined after one and three weeks, and the cultures were kept continuously in room temperature. Three parallel Petri dish cultures were grown from each sample: one on filter paper and two on agar.

The identification of the species was facilitated by establishing separate agar cultures of the fungi, especially those of the genera Botrytis, Fusarium and Sclerotinia. Selected, dried specimens from agar cultures were deposited in the University herbarium $(\mathrm{H})$.

The fungi were determined mainly according to von Arx (1981), Booth (1971; the Fusarium species), Domsch et al. (1980) and Ellis (1971).

\section{Results and discussion}

In the present study 20 species were determined; five could be identified only to the genera. Most of the fungi that developed are common saprophytes on many kinds of plant material and in soil (see Domsch et al. 1980, Ellis 1971). Investigations showed that there were three severe pathogens: Botrytis cinerea, Fusarium spp. and Sclerotinia sclerotiorum (Table 1). $B$. cinerea and $S$. sclerotiorum caused especially extensive and severe infections on the sunflowers.

S. sclerotiorum, which is a major pathogen of the sunflower in sunflower-growing areas (Zimmer \& Hoes 1978), chiefly destroyed the capitula, causing head rot, and the stems, causing basal rot, but was never found in the leaves. Sclerotinia first caused soft rot, then conspicuous external white mycelium formed and later the sclerotia developed. The fungus occurred only in the mycelial stage. On PDA the mycelium was white, and black sclerotia were formed. 
$B$. cinerea was common on capitula and stems. $B$. cinerea and $S$. sclerotiorum almost always occurred together in capitula, while Fusarium was seldom found in the same sample. In seven cases, $B$. cinerea was found alone, without Sclerotinia or Fusarium, which shows that this fungus can infect sunflowers independently as well as developing as a secondary parasite. $B$. cinerea was very common in the stem bases, where it often occurred together with Fusarium, but only once with $S$. sclerotiorum. On PDA $B$. cinerea formed black sclerotia, which were smaller than those of S. sclerotiorum. The culture was grayish and there were numerous conidiophores with conidia. $B$. cinerea is not considered a serious disease of the sunflower elsewhere, and is reported to occur when wet weather delays the harvest (Zimmer \& Hoes 1978).

Fusarium species were very common on rotted heads and stems. Fusarium species have not generally been recognized as serious sunflower pathogens (cf. Zimmer \& Hoes 1978). F. oxysporum has been isolated from the sunflower in Argentina (Sackston 1957), and Orellana (1971) has reported that Fusarium causes wilting in the sunflower in Texas. In the present study, however, Fusarium species frequently occurred in capitula, stems and leaves, especially in rotten stem bases. The most common Fusarium species were $F$. equiseti, $F$. oxysporum, $F$. sambucinum and $F$. avenaceum. The species $F$. culmorum and $F$. solani were isolated much more rarely (Table 1).

Together with Botrytis cinerea and Sclerotinia sclerotiorum the species of Fusarium form a disease complex which is very destructive on sunflower crops in Finland, at least when ripening and harvesting have been delayed. The other major pathogens of the sunflower, Puccinia helianthi Schw. and Verticillium dahliae Klebahn, were not found (Zimmer \& Hoes 1978).

The present fungus species have not been reported earlier growing on Helianthus annuus in Finland. The sunflower is rare as a weed and is not yet grown as an oil crop in this country, but is not uncommon as an ornamental.

Table 1. Fungi developed on Helianthus annuus in moist chambers.

Number of samples

Number of cultures

Fungi in cultures

Zygomycetes

Mucor sp.

Rhizopus sp.

Ascomycetes

Sclerotinia sclerotiorum (Lib.) de Bary $\begin{array}{llll}50 & 13 & 0\end{array}$

Deuteromycetes

Acremonium murorum (Corda) W. Gams

Acremonium sp.

Alternaria alternata (Fr.) Keissler

Arthrobotrys superba Corda

Aspergillus sp.

Botrytis cinerea Nocca \& Balbis

Cladosporium cladosporioides (Fres.) de Vries

C. herbarum (Pers.) Gray

Cylindrocarpon destructans (Zinssm.) Scholten

Fusarium avenaceum (Fr.) Sacc.

F. culmorum (W.G.Sm.) Sacc.

F. equiseti (Corda) Sacc.

F. oxysporum Schlecht.

F. sambucinum Fuckel

F. solani (Mart.) Sacc.

Fusarium sp.

Gliocladium roseum Bainier

Harzia acremonioides (Harz) Cost.

Trichoderma viride Gray

Trichothecium roseum (Pers.) Gray

Ulocladium consortiale (Thüm.)

E. Simmons

Verticilium tenerum (Pers.) Link

Verticillium $\mathrm{sp.}$

Unidentified fungi

\begin{tabular}{rrr}
\multicolumn{4}{c}{ capitula } & \multicolumn{3}{c}{ stems leaves } \\
18 & 15 & 5 \\
54 & 45 & 15 \\
& & \\
$\%$ & $\%$ & $\%$ \\
13 & 31 & 27 \\
0 & 33 & 53 \\
& & \\
50 & 13 & 0 \\
& & \\
& & \\
0 & 0 & 13 \\
22 & 15 & 0 \\
28 & 0 & 60 \\
0 & 11 & 0 \\
0 & 7 & 53 \\
72 & 80 & 0 \\
& & \\
6 & 0 & 20 \\
& & \\
& & \\
0 & 4 & 0 \\
0 & 27 & 20 \\
0 & 4 & 0 \\
6 & 35 & 40 \\
0 & 27 & 47 \\
0 & 40 & 27 \\
0 & 9 & 0 \\
11 & 7 & 27 \\
9 & 13 & 33 \\
0 & 0 & 20 \\
0 & 9 & 0 \\
0 & 7 & 0 \\
& & \\
9 & 33 & 27 \\
4 & 20 & 0 \\
11 & 7 & 0 \\
6 & 11 & 13 \\
& &
\end{tabular}

\section{References}

von Arx, J.A. 1981: The genera of fungi sporulating in pure culture. 3 rd ed., fully revised. $-424 \mathrm{pp}$. Vaduz.

Booth, C. 1971: The genus Fusarium. - 237 pp. Kew.

Domsch, K.H., Gams, W. \& Anderson, T.-H. 1980: Compendium of soil fungi $1-2$. $-859+495 \mathrm{pp}$. London.

Ellis, M.B. 1971: Dematiaceous Hyphomycetes. - 608 pp. Kew.

Orellana, R.G. 1971: Fusarium wilt of sunflower, Helianthus annuus: first report. - Plant Dis. Rep. 55:1124-1125

Sackston, W.E. 1957: Disease of sunflower in Uruguay. Plant Dis. Rep. 41: $885-889$.

Zimmer, D.E. \& Hoes, J.A. 1978: Diseases. In: Carter, J.F. (ed.), Sunflower science and technology. - Agronomy 19: $225-262$.

Accepted for publication on November 9, 1981 